\title{
The Effects of Sewage Discharge on The Marine Gastropod Gibbula sp., Collected From The Coast of Al-Hanyaa, Libya.
}

\author{
Ramadan A. S. Ali ${ }^{1}$ and Ahmed .S. Bream ${ }^{2}$ \\ 1- Zoology Department, Faculty of Science, \\ 2- Zoology Section, Faculty of Arts and Sciences, (Al-Qubba), Omar Al-Mukhtar \\ University, Al-Beidaa, Libya.
}

\section{ABSTRACT}

Marine gastropods are known to accumulate high metal concentrations in their tissues especially in the digestive glands. In this study, the accumulation of $\mathrm{Cu}, \mathrm{Zn}$, $\mathrm{Cd}, \mathrm{Cr}$ and $\mathrm{Pb}$ in the gastropod Gibbula sp. (Family: Trochidae) has been assessed using Atomic absorption, spectrophotometry graphite Furnace. Animals were collected from rocky shores at Al-Hanyaa region on the north-east coast of Libya. Two groups of animals were studied; one from an area adjacent to a sewage outlet and the second was collected from a relatively clean site. Concentrations of metals in the viscera, of both adults and juveniles, of Gibbula collected from the polluted site were higher than that recorded in the clean site. Thus, there is a tendency for Gibbula tissues in the polluted area to have higher concentrations of metals although the differences are not always statistically significant. The values recorded for adult specimens collected from the polluted and non polluted locations were $0.51 \pm 0.27$, $15.95 \pm 1.28,0.021 \pm 0.017,0.47 \pm 0.18,0.60 \pm 0.17$ vs $0.40 \pm 0.11,9.51 \pm 4.82,0.03 \pm$ $0.02,0.29 \pm 0.09,0.39 \pm 0.09$ for $\mathrm{Cu}, \mathrm{Zn}, \mathrm{Cd}, \mathrm{Cr}$ and $\mathrm{Pb} \mu \mathrm{g} / \mathrm{mg}$, respectively. Whereas, those recorded for juveniles were $0.51 \pm 0.09,17.02 \pm 1.13,0.032 \pm 0.01$, $0.49 \pm 0.15,0.54 \pm 0.17$ vs. $0.38 \pm 0.22,8.36 \pm 2.05,0.020 \pm 0.01,0.35 \pm 0.25,0.52 \pm 0.12$ for $\mathrm{Cu}, \mathrm{Zn}, \mathrm{Cd}, \mathrm{Cr}$ and $\mathrm{Pb} \mu \mathrm{g} / \mathrm{mg}$, respectively. It is suggested that metals are taken up by Gibbula sp. viscera directly from the water or from the ingested algae. Also, the shell mass was affected with the pollution.

Keywords: Bioindicators; Heavy metals, Mediterranean sea, Gibbula sp.

\section{INTRODUCTION}

Heavy metals are among the most common environmental pollutants, and their occurrence in waters and biota indicate the presence of natural or anthropogenic sources associated with industrial and domestic effluents (Biney et al.,1994; Zarazua et al., 2006). They can be easily accumulated by the primary consumer (algae), and biomagnified through their transmission across the higher levels of the food chain causing a direct effect on the human health (Page, et al., 1987). Lead, copper, cadmium, Chromium and arsenic were reported as the most toxic heavy metal pollutants (Hutton, 1987). The establishment of an efficient monitoring program to identify the contaminant in a given ecosystem became an important priority (AbdAllah and Bream, 2001).

Marine gastropods are known to accumulate high metal concentrations in their tissues, especially in the digestive glands. Gibbula is a genus of small sea snails, known as top snails or top shells, marine gastropod molluscs in the family Trochidae inhabiting the upper intertidal zone on rocky shores, where they graze on algal films 
or macroscopic algae. Many of them are very tolerant to exposure, living around the high tide mark with only brief periods of immersion.

Sewage effluent is often discharged via outfall into shallow subtidal habitats. Along the coasts of the Mediterranean Sea, despite a large amount of domestic and industrial sewage is discharged to the sea (USEPA, 2003), few published account exists concerning the effects of sewage effluents on gastropods inhabiting rocky shores. On rocky shores, sewage discharges can modify natural distribution patterns of sessile organisms. The impact of sewage on shallow hard substrate assemblages has been assessed along SW Apulian coast, Italy, (Terlizzi et al., 2002). The present study aimed to investigate the effects of a sewage discharge in Al Hanyaa city coastal region on the ecosystem using marine gastropods as biological monitors to prevent pollution wherever possible and to reduce risk for people and ecosystems.

\section{MATERIALS AND METHODS}

\section{Collecting of Samples}

The gastropod, Gibbula sp., was examined for heavy metal $(\mathrm{Cu}, \mathrm{Zn}, \mathrm{Pb}, \mathrm{Cd}$, and $\mathrm{Cr}$ ) levels in their soft parts. Samples were collected by hand from polluted and unpolluted sites located on the coast of Al-Hanyaa during fall 2009. Immediately after collection, snails were transferred fresh inside plastic containers to the laboratory. In the laboratory, all samples were washed with running distilled water. Prior to analysis, samples were classified, weighed and measured and the whole soft tissues o both adults and juveniles were removed from their shells and prepared for analysis. Specimen size was ranging between 1.2 and $1.5 \mathrm{~cm}$ shell length and $1.8-2.2 \mathrm{~cm}$ shell width, while the weight ranged between $5.0-6.2 \mathrm{gm}$ throughout the work to reduce possible variations in metal concentrations due to size and age (NAS, 1980) and to assure sampling of mature specimens. In addition, the impact of the outfall on juvenile Gibbula was also tested.

The soft tissues were weighed and wet digested in concentrated nitric acid and heavy metals levels have been determined in the digested tissues, and water samples using graphite furance atomic absorption spectroscopy instrument (Perkin Elmer) based on the method of McDaniel, 1991, and Kraak, et al., 1993. The concentration was calculated in $\mu \mathrm{g} / \mathrm{mg}$ fresh weight.

Observed bioaccumulation factors (BAFs) of these contaminants were calculated according to Harrahy and Clements (1997) using the following formula:

$$
\mathrm{BAF}=\mathrm{Ct} / \mathrm{CW}
$$

Where

$\mathrm{Ct}=$ tissue concentration

$\mathrm{Cw}=$ water concentration

\section{Statistical analysis}

Student's t-test was used to compare least square of means of metal concentration in different sites.

\section{RESULTS AND DISCUSSION}

The specimens of gastropods were sampled form two sites. The two locations were approximately 3-4 km from each other and situated on rocky shore. One considered polluted, located directly on the outfall (outlet of a sewage treatment station), the other used as a reference area "clean or unpolluted". The outfall serves more than 30,000 inhabitants. Waste waters are supposed to be biologically and 
chemically treated, by biwater company, before discharging. Trace metal concentrations in snails collected in September 2009 from these locations of AlHanyaa coast are presented in Tables 1-3 and plotted in Figs. 1-3. The results of specimens collected from polluted site showed that most metal concentrations in soft tissues of snails (adult and juvenile) were higher than that recorded in the clean site. Thus, there is a tendency for Gibbula tissues in the polluted area to had higher concentrations for all metals compared to clean area, although the differences are not always statistically significant. The attained results agree with those of Nicolaidou. and Nott, 1998 who stated that the concentrations of metals in the viscera of the gastropods Cerithium vulgatum and Monodonta mutabilis are higher than in the muscle and significantly higher in the animals from the polluted site. The same authors studied the uptake of metals by some gastropods, the accumulation sites and the release of the heavy metals in gastropods and found that these factors depend on the genera and the sites. Their findings proved that metals are accumulated within intracellular mineralized granules as phosphates and within lysosomal residual bodies in association with sulphur (Nott and Nicolaidou, 1989, 1990, 1994).

The highest accumulated metals were $\mathrm{Zn}$ and $\mathrm{Cu}$, while the lowest one was $\mathrm{Cd}$ in both adult and juvenile stage. The values recorded for adult specimens collected from the polluted and unpolluted locations were $0.51 \pm 0.27,15.95 \pm 1.28,0.021 \pm 0.017$, $0.47 \pm 0.18,0.60 \pm 0.17$ vs $0.40 \pm 0.11,9.51 \pm 4.82,0.03 \pm 0.02,0.29 \pm 0.09,0.39 \pm 0.09$ for $\mathrm{Cu}, \mathrm{Zn}, \mathrm{Cd}, \mathrm{Cr}$ and $\mathrm{Pb} \mu \mathrm{g} / \mathrm{mg}$, respectively. Similar results were recorded for juveniles, $0.51 \pm 0.09,17.02 \pm 1.13,0.032 \pm 0.01,0.49 \pm 0.15,0.54 \pm 0.17$ vs. $0.38 \pm 0.22$, $8.36 \pm 2.05,0.020 \pm 0.01,0.35 \pm 0.25,0.52 \pm 0.12$ for $\mathrm{Cu}, \mathrm{Zn}, \mathrm{Cd}, \mathrm{Cr}$ and $\mathrm{Pb} \mu \mathrm{g} / \mathrm{mg}$, respectively. It is suggested that metals are taken up by Gibbula sp. viscera directly from the water or from the ingested algae. Depending on the values of bioaccumulation factors, the relative bioconcentration variability of the studied dissolved metals in adults followed the order: $\mathrm{Pb}>\mathrm{Zn}>\mathrm{Cu}>\mathrm{Cr}>\mathrm{Cd}$ where the juvenile followed the order: $\mathrm{Pb}>\mathrm{Cu}>\mathrm{Cr}>\mathrm{Zn}>\mathrm{Cd}$. Similar results were obtained by Catsiki and Florou (2006) in the Saronikos and Thermaikos Gulf (Greece) with Mytilus galloprovinciallis.

Also, the shell mass was affected with the pollution where it is noticed that the shells of snails collected from the polluted sites were more fragile than those collected from the reference site. The agreed with that mentioned by Beeby et al., 2002, who found that $\mathrm{Pb}$, affected the shell growth of laboratory-bred offspring of Helix aspersa.

Further studies of metal levels in various other intertidal organisms from AlHanyaa rocky shore and the Libyan eastern coast, together with investigations into the possible effects of seasonal changes on metal concentration and distribution, are currently under way.

Table (1): Heavy metals concentrations (mg/L) determined in water samples

collected from the rocky shore of Al-Hanyaa, Libya.

\begin{tabular}{|c|c|c|c|c|c|}
\hline Location/Metal & $\mathrm{Cu}$ & $\mathrm{Zn}$ & $\mathrm{Cd}$ & $\mathrm{Cr}$ & $\mathrm{Pb}$ \\
\hline Polluted & 0.6 & 7.4 & 0.07 & 0.32 & 0.4 \\
\hline Unpolluted & 0.24 & 5.4 & 0.03 & 0.22 & 0.2 \\
\hline
\end{tabular}

Table 2: Heavy metals concentrations ( $\mu \mathrm{g} / \mathrm{mg}$ wet weight) determined in Gibbula adults collected from two sites of the rocky shore of Al-Hanyaa, Libya.

\begin{tabular}{|c|c|c|c|c|c|}
\hline Location/Metal & $\mathrm{Cu}$ & $\mathrm{Zn}$ & $\mathrm{Cd}$ & $\mathrm{Cr}$ & $\mathrm{Pb}$ \\
\hline Polluted & $0.51 \pm 0.27 \mathrm{a}$ & $15.95 \pm 1.28 \mathrm{a}$ & $0.021 \pm 0.017 \mathrm{a}$ & $0.47 \pm 0.18 \mathrm{a}$ & $0.60 \pm 0.17 \mathrm{a}$ \\
\hline BAFs & 1.0 & 2.2 & 0.3 & 1.2 & 1.5 \\
\hline Unpolluted & $0.40 \pm 0.11 \mathrm{a}$ & $9.51 \pm 4.82 \mathrm{c}$ & $0.03 \pm 0.02 \mathrm{a}$ & $0.29 \pm 0.09 \mathrm{~b}$ & $0.39 \pm 0.09 \mathrm{c}$ \\
\hline BAFs & 1.7 & 1.8 & 1.0 & 1.3 & 2.0 \\
\hline
\end{tabular}

Means followed with the same letter are not significantly different. 
Table 3: A comparison of heavy metal concentrations ( $\mu \mathrm{g} / \mathrm{g}$ wet weight) determined in Juvenile individuals of Gibbula sp. collected from polluted and unpolluted sites of Al-Hanyaa, Libya.

\begin{tabular}{|c|c|c|c|c|c|}
\hline Location/Metal & $\mathrm{Cu}$ & $\mathrm{Zn}$ & $\mathrm{Cd}$ & $\mathrm{Cr}$ & $\mathrm{Pb}$ \\
\hline Polluted & $0.51 \pm 0.09 \mathrm{a}$ & $17.02 \pm 1.13 \mathrm{a}$ & $0.32 \pm 0.01 \mathrm{a}$ & $0.49 \pm 0.15 \mathrm{a}$ & $0.54 \pm 0.17 \mathrm{a}$ \\
\hline BAFs & 0.9 & 2.3 & 4.6 & 1.5 & 1.4 \\
\hline Unpolluted & $0.38 \pm 0.22 \mathrm{a}$ & $8.36 \pm 2.05 \mathrm{c}$ & $0.020 \pm 0.01 \mathrm{a}$ & $0.35 \pm 0.25 \mathrm{a}$ & $0.52 \pm 0.12 \mathrm{a}$ \\
\hline BAFs & 1.6 & 1.5 & 0.7 & 1.6 & 2.6 \\
\hline
\end{tabular}

Means followed with the same letter are not significantly different.

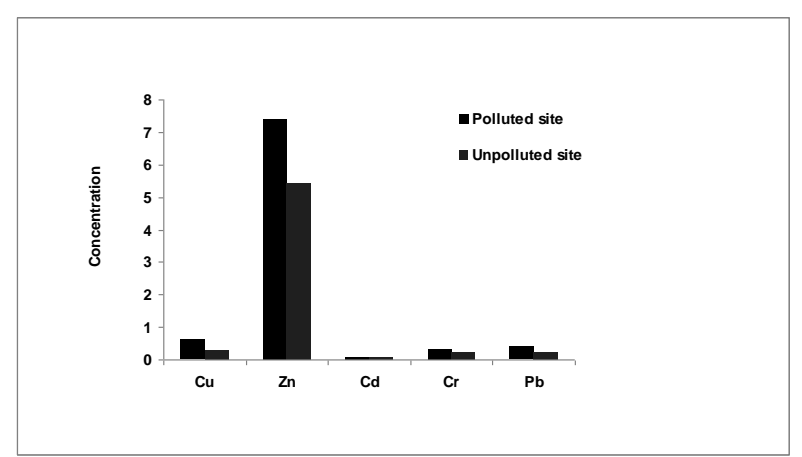

Fig. 1: Heavy metals concentrations $(\mathrm{mg} / \mathrm{l})$ determined in water samples collected from the rocky shore of Al-Hanyaa, Libya.

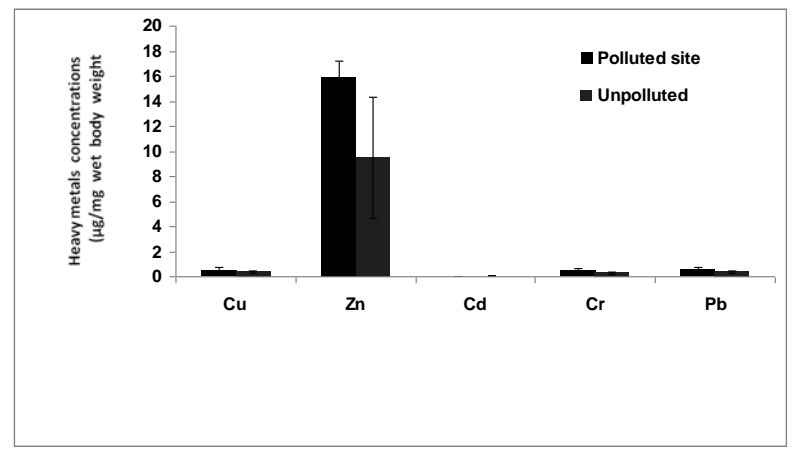

Fig. 2: A comparison of heavy metal concentrations ( $\mu \mathrm{g} / \mathrm{mg}$ wet body weight) determined in adults and Juvenile individuals of Gibbula sp. collected from Al-Hanyaa coast.

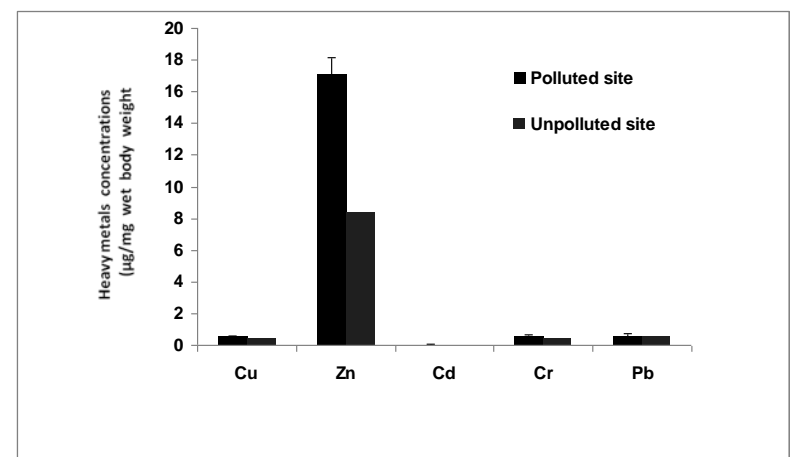

Fig. 3: A comparison of heavy metal concentrations ( $\mu \mathrm{g} / \mathrm{mg}$ wet body weight) determined in adults and Juvenile individuals of Gibbula sp. collected from Al-Hanyaa coast. 


\section{REFERENCE}

Abd-Allah, A. T. and Bream, A. S. (2001): "Investigations on the efficiency of some freshwater invertebrates as biological monitors for heavy metal pollution". J. Egypt. Acad. Soc. Environ. Develop., (D-Environ. Studies) 2 (2): 67-80.

Beeby' A.; Richmond L. and Florian H. (2002). Lead reduces shell mass in juvenile garden snails» (Helix aspersa) Environmental Pollution 120 (2): 283-288

Biney C.; Amuzu A.T.; Calamari D.; Kaba N.; Mbome I.L.; Naeve H.; Ochumba P.B.O.; Osibanjo O.; Radegonde V. and Saad M.A.H., (1994). Review of pollution in the African aquatic environment. FAO, Rome.

Catsiki V. A. and Florou H. (2006). Integrated use of biomarkers (superoxide dismutase, catalase and lipid peroxidation) in mussels Mytilus galloprovincialis for assessing heavy metals' pollution in coastal areas from the Saronikos Gulf of Greece. J. Environ. Radiact. 86: 31- 44

Harrahy, E A. and Clements, W.H. (1997). Toicity and bioaccumulation of heavy metals in Chironomus tntans. Environ. Toxoicol. Chem, 16(2): 317-327.

Hutton, M. (1987). Human health concerns of Lead, Mercury, Cadmium and Arsenic. In " Lead, Mercury, Cadmium and Arsenic in Environment" pp. 53-68. (SCOPE 31). John Wiley and Sons.

Kraak, M. H. S.; Toussaint, M.; Bleeker, A. J. and Lavy, D. (1993). Metal regulation in two species of freshwater bivalve. In "Ecotoxicology of Metals in Invertebrates" edited by Dallinger and Rainbow, first edition, pp175-186. SETAC special publication series, Lewis Publishers, Ann Arbor, London, Tokyo.

McDaniel, W. (1991). Sample preparation procedure for spectrochemical determination of total recoverable elements in biological tissues. In "Revision 1.0 Environmental Monitoring Systems Laboratory" pp. 23-29. EPA.

NAS (1980). The International Mussel Watch, National Academy of Sciences, Washington, DC 213 pp.

Nicolaidou, A. and Nott, J.A. (1990). Mediterranean pollution from a Ferro-nickel smelter: differential uptake of metals by some gastropods. Marine Pollution Bulletin 21:137143.

Nicolaidou, A. and Nott, J. A. (1998). Metals in sediment, seagrass and gastropods near a nickel smelter in Greece: Possible interactions. Marine Pollution Bulletin, 36 (5): 360-365.

Nott, J. A. and Nicolaidou, A. (1989). Metals in gastropods-metabolism and bioreduction Marine Environmental Research, Vol. 28(1-4): 201-205.

Nott, J. A. and Nicolaidou, A. (1994). Variable transfer of detoxified metals from snails to hermit crabs in marine food chains. Marine Biology, 120, 369-377.

Page, A. I.; Chang, A.C. and El-Amamy, M. (1987). Cadmium levels in soils and crops in United States. In "Lead, Mercury, Cadmium and Arsenic in the environvement" (SCOP31). Edited by Hitchinson and Meema, Published by John Wiley and Sons. Chiechester. New York. Brisbane.Torento. Singapor.

Terlizzi, A.; Fraschetti, S.; Guidetti P. and Boero F. (2002). The effects of sewage discharge on shallow hard substrate sessile assemblages. Marine pollution Bulletin. 44 (6): 544-550.

USEPA (2003). Draft Update of Ambient Water Quality Criteria for Copper. EPA 822-R-03026.

Zarazua G.; Ávila-Pérez P.; Tejeda S.; Barcelo-Quintal I. and Martínez T., (2006). Analysis of total and dissolved heavy metals in surface water of a Mexican polluted river by Total Reflection X-ray Fluorescence Spectrometry. Spectrochimica Acta Part B: Atomic Spectroscopy, 61, 1180-1184. 


\section{ARABIC SUMMARY}

تأثيراتُ صرف مياه المجاري على البطنقدميات البحرية من نوع جيبيولا المجمعة من ساحل الحنية, ليبيا

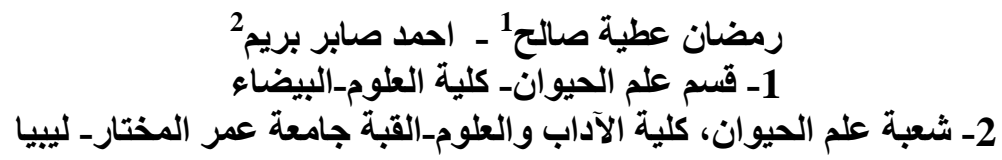

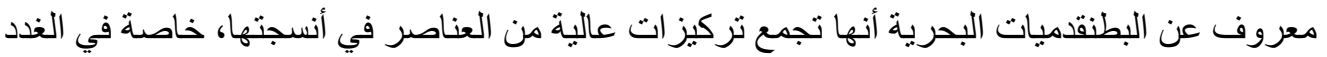

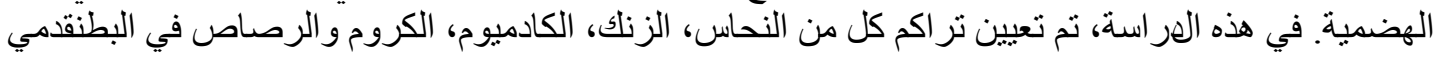

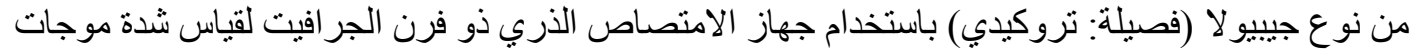

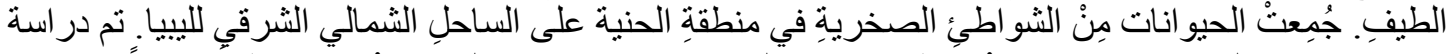

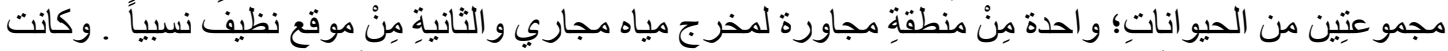

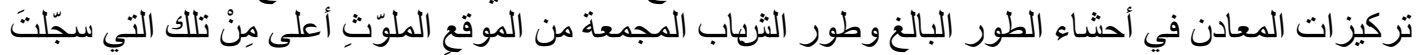

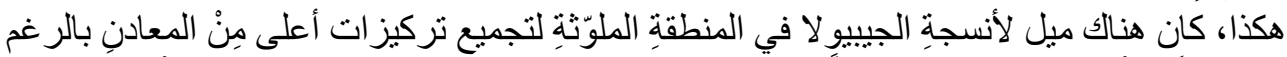
في الموقع النظيفِ

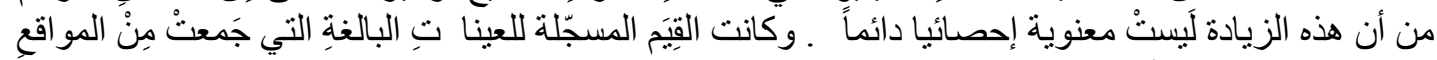

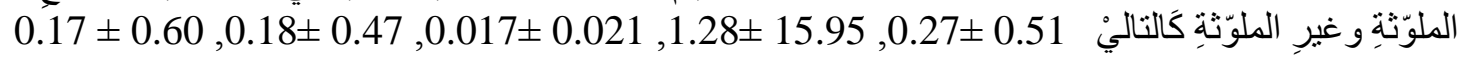

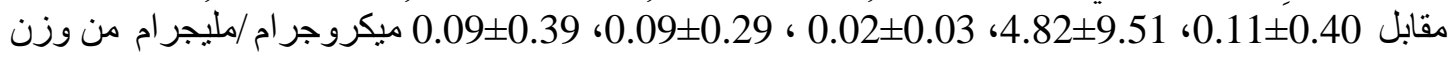

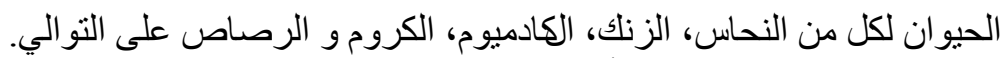

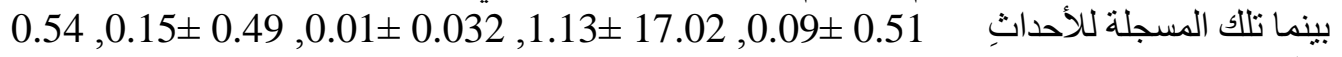

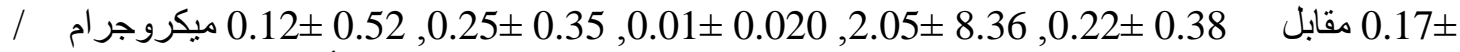

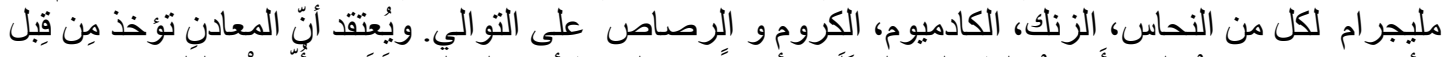

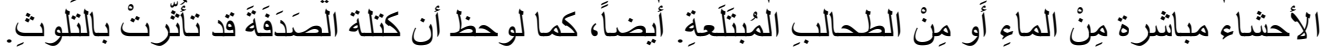

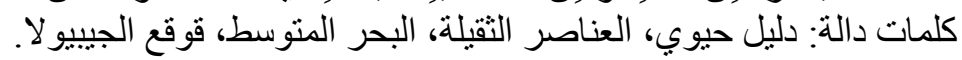

